\title{
NRAS Exon 3 Mutation
}

National Cancer Institute

\section{Source}

National Cancer Institute. NRAS Exon 3 Mutation. NCI Thesaurus. Code C135719.

A molecular genetic abnormality indicating the presence of a mutation in exon 3 of the NRAS gene. 